\title{
Социология
}

\section{THE STREET ART'S ABILITY TO RAISE SOCIALLY SIGNIFICANT PROBLEMS}

\author{
U.S.Shvindt, uliana_s@list.ru, \\ Ural Federal University, Yekaterinburg, Russian Federation
}

The author of the article considers the main current street art's characteristic which lies in the fact that it might and should address the issues of social, political, philosophical, environmental etc. nature. In particular this main feature is aimed at the engagement of audience, that is city residents, in dialogue. In accordance with this, the author of the article gives some examples of particular street art works, which reflect the described characteristic of this kind of art. In order for illustrative purposes the article presents and analyses famous world and Russian street art pieces. In the consideration of Russian street art works' content the author concentrates on the pieces of street artists from Yekaterinburg, which is noted for its big amount of original street art works and is recognized as a capital of Russian street art.

Keywords: street art, street artists, Banksy, Yekaterinburg street art, T-Radya.

Street art is one of the forms of current contemporary art. On the one hand, street art is a relatively new phenomenon that has strongly marked urban nature and that is capable of existing only within public city space. Herewith, it interacts with the urban environment complementing and aestheticizing it or, on the contrary, disfiguring it with its irrelevance and unattractiveness [8, p. 3]. On the other hand, street art is a socio-cultural phenomenon suggesting that its works can be considered not only in a physical sense but also as an object reflected in consciousness $[8, p .3]$. It is a cultural concept and at the same time a product of culture embodied in certain socio-cultural space-time and constantly produced and reproduced in various social practices [2].

The most important feature of street art is that, as has already been said, it often embodies ideas relevant to contemporary realities and hereby reflects problems of a social, political, cultural, etc. focus. In order to more clearly examine this feature we should analyze the most vivid examples of such nature of the street artists' messages. One of the most famous figures in this regard is English street artist Banksy. A large number of his works are drawn to the acute problems of modern society. Thus, for example, Napalm (2004) depicts Mickey Mouse and Ronald MacDonald leading a crying little girl by the hand. This image Banksy borrowed from the famous photograph of Nick Ut made during the Vietnam War and depicting a Vietnamese girl escaping from exploded napalm. The work holds and demonstrates the critique of modern society: the symbols of American culture - "Mickey Mouse and Ronald MacDonald — represent a consumer' greed and a self-deception of people who willingly close their eyes to more serious problems" [3], for example, world wars. Another work of Banksy The Flower Thrower (2005) depicts a rebel which keeps in his hand and throws a bouquet of flowers instead of a cocktail bomb. It's quite simply to understand this work's idea: the artist seeks to show that with the help of peaceful means instead of cruelty and aggression one can achieve much more goals. In 2006 the installation London Phone Booth made by him has emerged in London. In this case the true meaning of the artist's message is unknown, however, according to some art historians, the work symbolizes the devaluation of the real-life communication culture in the era of development and the increasing influence of the Internet and social networks. As one more, the last, example of Banksy works we can recall the one called Jungle (which was installed in Calais in 2015). Here Banksy depicts Steve Jobs as a migrant from Syria. With his work Banksy wanted to argue that not all migrants are terrorists, a striking example of which is Steve Jobs, the son of a Syrian refugee who came to the United States.

Apart from Banksy, many other well-known world street artists choose acute social and political problems as the plot of their works. Thus, Os Gemeos, a team of street artists that are twin brothers from São Paulo, raise in their works the problems of corruption and social inequality. In one of their works, besides the painting itself, there is a striking writing: "How much does a member of the municipal council earn? And how much does a teacher earn?". The writing of even more provocative their object states: "I love my Brazil ... But not politicians!".

A street artist from Italy with a nickname Blu, who paints murals all over the world, in a rather paradoxical way combines humor, criticism and a kind of satire about modern society in his creative works. His works themselves are executed in a humorous manner and can cause a smile when they are firstly encountered by someone, but upon more closer examination it becomes clear that they are deeply philosophical and, as some experts in the field of street art note, even pretty much brilliant. The figure 1 represents one of these works: the key-note that this object broadcasts is that in the world of constant consumption and satisfaction of our infinite needs humanity ceases to care for the planet depriving it of its resources.

The problem of ecology is also reflected in the works of some other street artists. For example, the team from Switzerland Nevercrew became famous in the world of art for their images of whales, pandas, polar bears that are marginal animals (Fig. 2). So, for example, the 


\section{Социология}

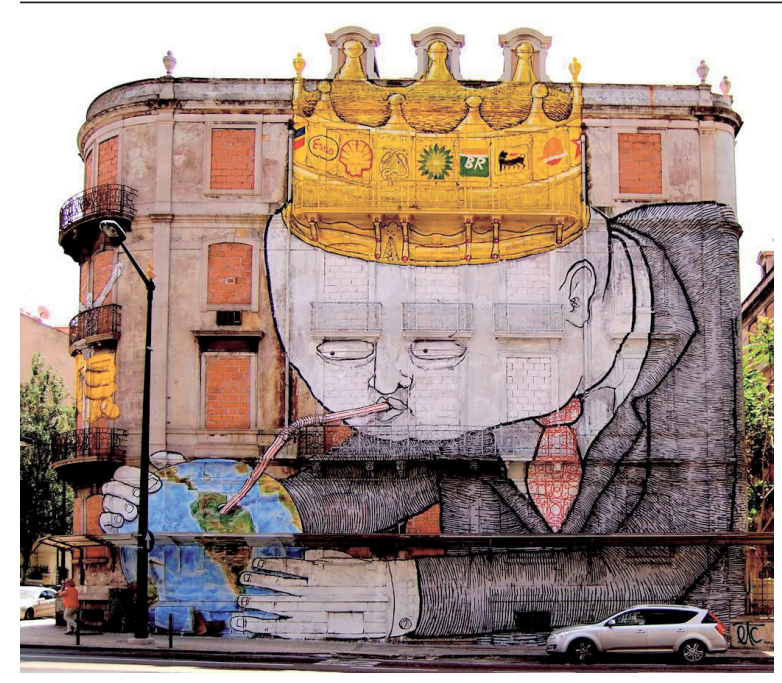

Fig. 1. Work raising the problem of ecology. Author: Italian street artist Blu. The photo is borrowed from the lodged to the artist website: https://www.blublu.org/

whale in their works is depicted in the dust of manmade waste, and in another object - it is placed in a city with a high level of anthropogenic pollution. The main idea, raised by the artists, is about to show that humans do not contribute to the preservation of wildlife but, on the contrary, constantly enter into confrontation with it. These actions definitely lead to the very harmful consequences.

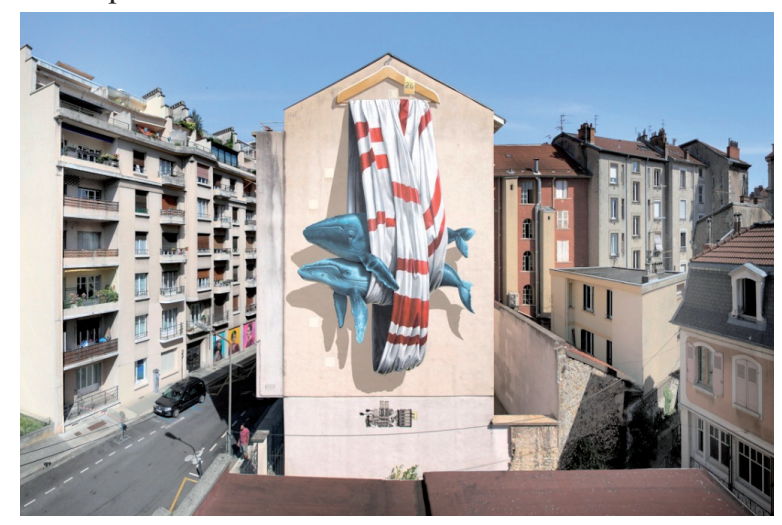

Fig. 2. Work that raises the problem of the environmental 'insecurity' of some animals. The photo is borrowed from the artists' website: http://www.nevercrew.com/

Another street artist from Italy, who took the nickname Mr. Thoms, is known for his works with a pronounced humorous and partly sarcastic style. In this way, one of the objects of this artist shows us a man of the modern world: he is obsessed with getting 'likesfor-likes' on the social media Facebook. At the same time he is wearing blinders which symbolizes escaping from the real world, its complete disregard in favor of the Internet and social media. His another work contains a writing "Someone ... plays your game" and depicts a man in whose head two other men play chess. It is being addressed to every single individual and demonstrates how dangerous may be to yield to a kind of a pressure and trust the life to someone else.

Street artists from Russia also tend to express in their works philosophical messages about the state and development of modern society. One of the most famous
Russian artists ever Pavel 183 turned to social issues in every single case. He was often called and is still called 'the Russian Banksy' because of, first, his fame, and, second, the similarity of the problems that he raised with the problems that are brought up by the street art objects of the English artist. For that matter the painting he created in 2013 refers to Hans Christian Andersen's fairytale The Girl with the Matches. In accordance with its plot, the little girl who left alone tried to warm herself with a box of matches but they soon ended and the next morning people found her dead. Another his work shows us a homeless person with the angel's wings lying on the ground and calling out: "Give for the ticket home". Pavel 183 has noted that homeless people "sometimes look absolutely horrible, but at the same time ... they are deprived of those harmful irritants that disfigure people ... They are often ... cleaner and more enlightened than anyone ... and nobody helps them, and if they do, then seldom" [6].

Another Russian street artist from Kazan working under the nickname Qbic painted a mural on the wall of one house pictured people whose faces literally 'are blooming' in the process of reading books. The artist's message is quite obvious: he seeks to highlight the importance of paying much attention to the intellectual component of life. The artist from Moscow Aleksey Mednoy has addressed his work to the problem of animal abuse. In this way, he created a mural pictured animals traditionally performing in a circus and wrote the following text in big letters: "For a circus without animals". By this art work Aleksey Mednoy tried to confront the very idea of a circus where animals are being subjected to violence.

Street artists from Yekaterinburg Tima Radya and Slava PTRK currently are considered as the most socially engaged artists in Russia. Thus, one of the works of Tima Radya presents a kind of pyramid built of police shields and held a throne on its top. This art object is called Stability and is made as a temporary installation that falls even when it is slightly breezing, thus symbolizing the precariousness of the vertical power structure [7] (Fig. 3). In 2013 Radya has taken a prize of the New York Frieze Art Fair 'Cutlog' for this critical art piece.

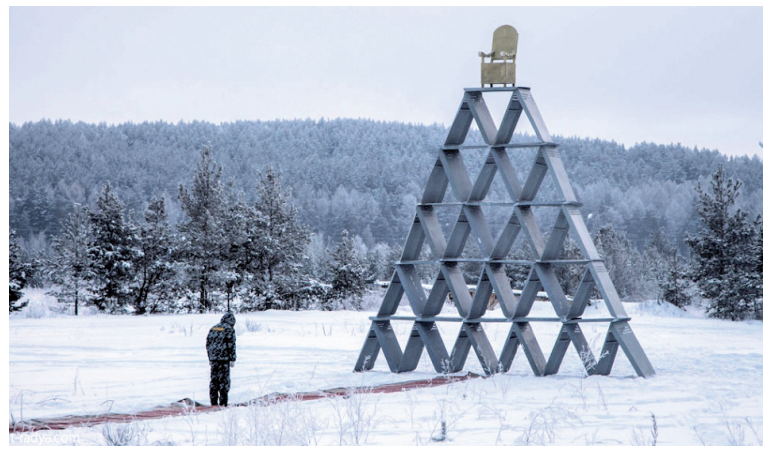

Fig. 3. The street art work Stability, Yekaterinburg. Author: Tima Radya. Source: the artist's website http://t-radya.com/

Very often street artists from Russia devote their works to the subject of the Great Patriotic War. The Radya's piece Eternal Light carries on this tradition. To present such a work he, together with a group of likeminded people, has managed to make a performance. 
Radya has made six large-scale portraits of the Great Patriotic War heroes picking a cocktail bomb as a means of expression. The burning of the soldiers' faces in this performance symbolized the horrors they had to face. This work itself represents tribute to those who fought for their country.

Slava PTRK (this is the nickname of the artist; his real name is Stanislav Komissarov) is also known for his works that raise various social problems. For example, his social project Street Mud is a series of works each of which depicts a homeless person (Figure 4). The artist has chosen such a plot to pay attention to the subject of homeless people, to which passers-by often turn a blind eye, seeing them as street dirt and furthermore not noting human in them [4].

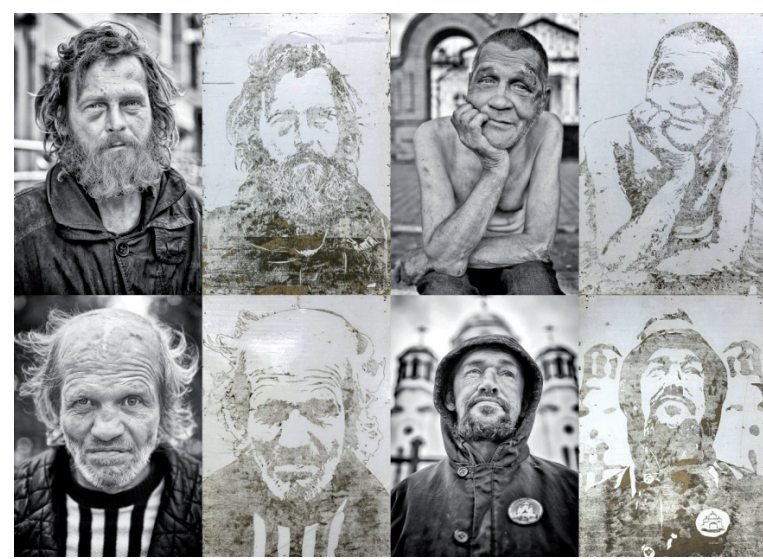

Fig. 4. The work Street Mud. Author: Slava PTRK.

The picture is borrowed from the website: http://www. rupolit.net/

Another significant artist, whose creative work was in the origins of both Yekaterinburg and all Russian street art, is Evgeny Malakhin (commonly known as simply Old Man Bukashkin). He is quite famous figure in the art field, especially contemporary art field, of Yekaterinburg. His pictures are made in a quite simple manner but they pay attention to important humanistic values. Bukashkin promoted such commonplace truths as a healthy lifestyle, kindness, caring for people and animals, etc [1]. By 2011 almost all of his drawings had been lost. However, his followers that is the art movement 'Old Man Bukashkin' have recreated some of them and also have drawn new ones in the same manner. Figure 5 represents one of these recreated drawings.

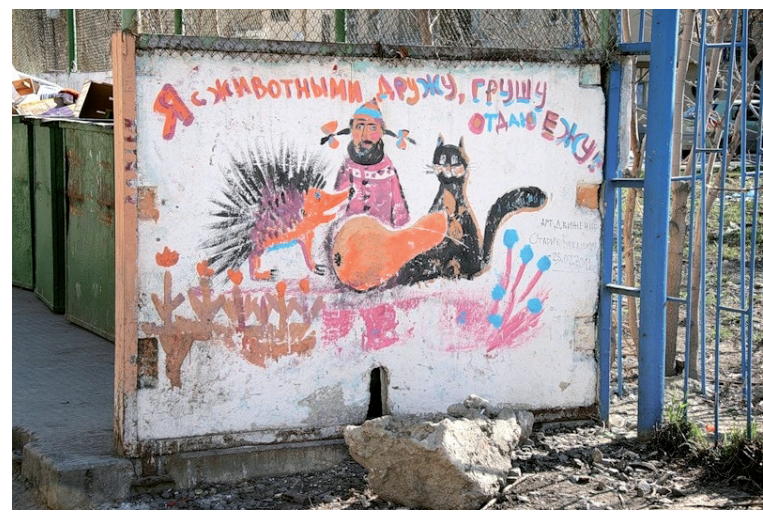

Fig. 5. One of the recreated drawings of Evgeny Malakhin (Old Man Bukashkin). Source: https://ural-n.ru/p/dvorikstarika-bukashkina.html
And one more well-known in Yekaterinburg street artist Alexander BLOT with his work Don Quixote (Fig. 6) demonstrates how he interprets the street artists' activities: in it he compares them with the famous hidalgo since they both seek to bring goodness in the world yet remaining in the position of constant fight. It is interesting to note that in the place, where this art object is located, there are several other similar houses which are particularly had been well-loved by many other street artists who subsequently have placed their works there. That's because during the creation of the first object (by Alexander BLOT) the other houses residents had loved the idea and the drawing itself so much that they have asked the artists to cover their houses with drawings too.

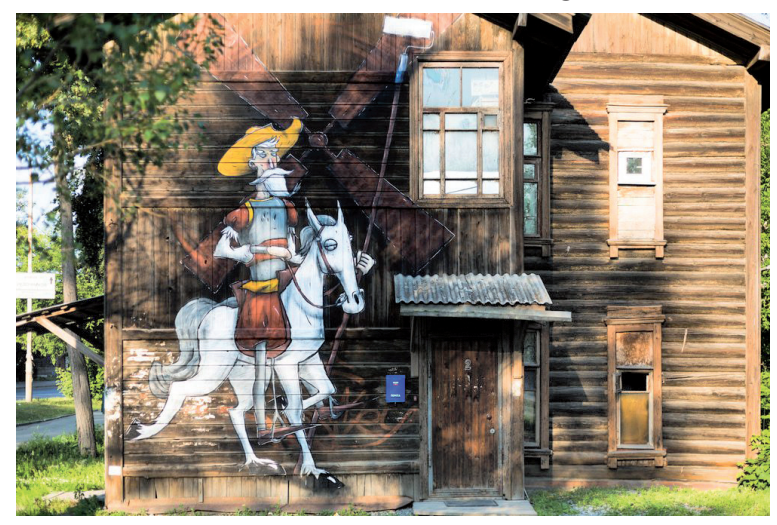

Fig. 6. The work Don Quixote by the street artist Alexander BLOT. The photo is borrowed from the website: https:// nashural.ru/sobytiya/festival-stenograffiya/.

As we can see, the present survey of some famous street art pieces (in the world, Russia and Yekaterinburg) clearly demonstrates that street artists seek to raise in their works the problems of social, political, cultural, etc. focus that are significant for them and for the whole society. From this we can conclude that street art is primarily characterized by such an important feature as relevance that means that street art, by its nature, is a relevant art.

\section{References}

1. Kostina D. A. Vizual'nye praktiki v gorodskom prostranstve: strategii funktsionirovaniia i praktiki osvoeniia [The visual practices in city space: the strategies of functioning and the practices of development] [Electronic resource] / D. A. Kostina, E. V. Iuzhakova// Izvestiia Ural'skogo Federal'nogo Universiteta [The news of Ural Federal University]. — 2013. - №1 (110). — P. 141-148. - Mode of access: http://elar.urfu.ru/bitstream/10995/19356/1/18-110.pdf.

2. Palamarchuk M. L. Gorod kak sotsiokul'turnyi fenomen [City as a socio-cultural phenomenon] [Electronic resource]: syn. of diss. ... cand. of philosophy: 09.00.11 / M. L. Palamarchuk; Murmanskii arkticheskii gosudarstvennyi universitet [Murmansk State Arctic University]. - Murmansk, 2009. - 21 p. - Mode of access: http://cheloveknauka.com/ gorod-kak-sotsiokulturnyy-fenomen.

3. Popova N. Evoliytsiia Mikki Mausa [Evolution of Mickey Mouse] [Electronic resource] / N. Popova // RIA. ru. - 2013. - November 18. - Mode of access: https://ria. ru/weekend cinema/20131118/975337414.html.

4. Slava PTRK. Sotsial'nyi proekt Ulichnaia Griaz' [Slava PTRK. The social project called Street Mud] [Electronic resource] // CITYCELEBRITY. - 2014. - July 1. Mode of access: http://citycelebrity.ru/citycelebrity/Post. aspx?PostId=82538. 


\title{
Социология
}

5. Web-site of street artist T-Radya. Mode of access: http://t-radya.com/.

6. Ulichnyi khudozhnik Pavel 183: interv'iy pered smert'iy [Street artist Pavel 183: the interview before death] [Electronic resource] // BBC News. - 2013. - April 4. - Mode of access: https://www.bbc.com/russian/russia/2013/04/130404_street_ art p183 interview.

7. Tsygina N. A. Kontekstual'nost' kak osnovopolagaiyshchee svoistvo ulichnogo iskusstva [Contextuality as a basic characteristic of street art] [Electronic resource] / N. A. Tsy'gina // Vestnik Moskovskoi khudozhestvenno-promyshlennoi akademii imeni S. G. Stroganova [The Bulletin of Moscow State Stroganov Academy of Industrial and Applied
Arts]. - 2014. - №1. - P. 295-305. - Mode of access: https:// elibrary.ru/item.asp?id=21246590.

8. Shvindt U. S. Strit art kak sotsial'no-kul'turnyi fenomen sovremennogo gorodskogo prostranstva (na primere Ekaterinburga) [Street art as a socio-cultural phenomenon of the modern city space (by the example of Yekaterinburg)]: master's dissertation: 39.04.01 / U. S. Shvindt; Ural'skii federal'nyi universitet [Ural Federal University]. - Yekaterinburg, 2018. - $163 \mathrm{p}$.

9. Web-site of street artist Blu. Mode of access: https:// www.blublu.org/.

10. Web-site of street artists' team Nevercrew. Mode of access: http://www.nevercrew.com/.

Received May 17, 2019

\section{СПОСОБНОСТЬ УЛИЧНОГО ИСКУССТВА ПОДНИМАТЬ ОБЩЕСТВЕННО ЗНАЧИМЫЕ ПРОБЛЕМЫ}

\section{У. С. Швиндт,}

Уральский федеральный университет, г. Екатеринбург, Российская Федерация

\begin{abstract}
Автор статьи рассматривает основную характерную особенность современного уличного искусства, которая заключается в том, что оно способно и должно затрагивать проблемы социального, политического, философского, экологического и др. характера. Именно эта черта направлена на то, чтобы вовлекать аудиторию - городское население - в диалог. В соответствие с этим автор приводит некоторые примеры конкретных работ уличного искусства, в которых отражена данная особенность этого вида искусства. В статье в качестве примеров представлены и проанализированы известные мировые и российские произведения уличного искусства. Особый акцент в анализе содержания работ российского уличного искусства автор делает на работах художников из г. Екатеринбурга, который известен большим количеством оригинальных произведений и признается столицей российского уличного искусства.

Ключевые слова: уличное искусство, уличные художники, Бэнкси, уличное искусство Екатеринбурга, Тимофей Радя.
\end{abstract}

\section{Литература и источники}

1. Костина, Д. А. Визуальные практики в городском пространстве: стратегии функционирования и практики освоения / Д. А. Костина, Е. В. Южакова // Известия Уральского федерального университета. — 2013. — №1 (110). C. 141-148. — URL: http://elar.urfu.ru/bitstream/10995/19356/1/18-110.pdf.

2. Паламарчук, М. Л. Город как социокультурный феномен : автореф. дис. ... канд. филос. наук: 09.00.11/ М. Л. Паламарчук ; Мурманский арктический государственный университет. — Мурманск, 2009. — 21 c. — URL: http:// cheloveknauka.com/gorod-kak-sotsiokulturnyy-fenomen.

3. Попова, Н. Эволюция Микки Мауса / Н. Попова // RIA.ru. — 2013. — 18 нояб.. — URL: https://ria.ru/weekend cinema/20131118/975337414.html.

4. Швиндт, У. С. Стрит арт как социально-культурный феномен современного городского пространства (на примере г. Екатеринбурга) : магистерская дис. : 39.04.01 / У. С. Швиндт ; Урал. федер. ун-т им. первого Президента России Б. Н. Ельцина. - Екатеринбург, 2018. - 163 с.

5. Слава ПТРК. Социальный проект Уличная Грязь // CITYCELEBRITY. — 2014. — 1 июля. — URL: http://citycelebrity. $\mathrm{ru} /$ citycelebrity/Post.aspx?PostId=82538.

6. Цыгина, Н. А. Контекстуальность как основополагающее свойство уличного искусства / Н. А. Цыгина // Вестник Московской художественно-промышленной академии им. С. Г. Строганова. - 2014. - № 1. - С. 295-305. - URL: https://elibrary.ru/item.asp?id=21246590.

7. Уличный художник Павел 183: интервью перед смертью // BBC News. — 2013. — 4 aпр.. — URL: https://www.bbc. com/russian/russia/2013/04/130404 street art p183 interview.

8. Blu : сайт уличного художника. - URL: https://www.blublu.org/.

9. Nevercrew :сайт команды художников. — URL: http://www.nevercrew.com/.

10. Тимофей Радя : сайт уличного художника. — URL: http://t-radya.com/.

Received May 17, 2019

ШВИНДТ Ульяна Сергеевна, аспирантка кафедры прикладной социологии, Уральский федеральный университет, Екатеринбург, Российская Федерация. E-mail: uliana_s@list.ru

ОБРАЗЕЦ ЦИТИРОВАНИЯ

Shvindt U. S. The street art's ability to raise socially significant problems // Вестник ЮУрГУ. Серия «Социальногуманитарные науки». - 2019. - Т. 19, № 3. C. 105 -108. DOI: $10.14529 / \mathrm{ssh} 190315$

\section{FOR CITATION}

Shvindt U. S. The street art's ability to raise socially significant problems. Bulletin of the South Ural State University. Ser. Social Sciences and the Gumanities. 2019, vol. 19, no. 3 , pp. 105-108. DOI: $10.14529 / \mathrm{ssh} 190315$ 